All issues of this journal are alternatively stored and archived by: the National Library of Thailand, Russian E-library and Index Copernicus library of journals, Poland

\title{
IS BEHAVIOR FINANCE AFFECTED BY INCOME, LEARNING FINANCE AND LIFESTYLE?
}

\author{
Aulia Rahman \\ Asep Risman \\ University Mercu Buana, Jakarta, Indonesia
}

The purpose of this study is to determine whether there is a relationship between financial behavior based on income, financial literacy and a personal lifestyle. This study uses primary data through a data collection process by distributing questionnaires online (using Google Forms) among the total of 50 respondents. The data analysis technique used here is SPSS, version 25. The results of this study indicate that there is a significant positive effect between financial literacy variables and financial behavior. Meanwhile, income and lifestyle variables seem to have no influence on financial behavior.

Keywords: income, financial literacy, life style, financial behavior

\section{Introduction}

Managing finances is something that humans do in everyday life. Financial management plays a role and affects the fulfillment of human needs and desires. If someone manages finances well, their needs and desires will be fulfilled.

Income is an important factor in order to fulfill these needs and wants. Income is defined as the total amount of money received by a person or a household during a certain period of time (usually one month). Income can be in the form of wages/salaries, income
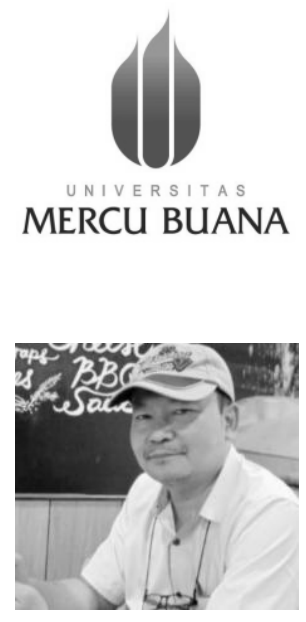

\section{Aulia Rahman}

Researcher, Faculty of Economy and Business, University "Universitas Mercu Buna", Jakarta Indonesia

Research interests: banking and financing, international financial markets

Email: rahmanaulia011@gmail.com

\section{Asep Risman}

Lecturer of University "Universitas Mercu Buna”, Jakarta Indonesia.

Research interests: corporative finance, corporative management, behavioral finance, international and national business development

E-mail: asep.risman@mercubuana.ac.id 


\section{IS BEHAVIOR FINANCE AFFECTED BY}

may also come from wealth such as rent, interest and dividends, as well as transfer payments or receipts from the government such as social benefits, scholarship or unemployment insurance (Herawati, 2015).

Meanwhile, Dwinta (2010) interpret personal income as the total annual gross income of an individual that comes from wages, business enterprises, and various investments.

The next factor in our research study is financial literacy. According to the OJK Financial Services Authority (2017), financial literacy is knowledge, skills, and beliefs that influence attitudes and behavior to improve the quality of decision-making and financial management in order to achieve prosperity. Understanding of financial literacy may be helpful for us in financial management since it directly concerns the ability to manage finances properly and responsibly.

Therefore, we can hope that through financial literacy the desired level of community socioeconomic life will increase, primarily because personal income level may become nothing without one's ability to manage own finances properly. Taken together, income level and financial literacy help achieve a certain level of financial safety (security). Unfortunately, till now, many people still do not understand finance as such.

Lifestyle is one of the key factors that describe the "whole person" in its interaction with the environment. Lifestyle is a certain pattern of a person's life, expressed through activities, interests, and opinions overall and in particular - those related to spending money and allocating the time a person has at their disposal. Lifestyle is mostly formed through social interaction. Lifestyle is a way that a person takes in living their, it covers activities, interests, attitudes, consumption and expectations. According to Fudyartanta (2012), the student's lifestyle, for example, may change, but this change is not caused by changing needs. During puberty, it's no longer the parents who are the role models, but rather all surrounding people in general.

\section{Literature Review and Research Hypothesis}

\section{Income}

Based on the research conducted by Hilgert et al. (2003), the respondents with high incomes are more punctual in reporting their bill payments as compared to those with lower incomes. In Andrew \& Linawati (2014), the respondents stated that those with lower incomes tend to pay bills less on time than those with higher incomes.

\section{Financial Literacy}

Simply put, financial literacy is a person's financial knowledge (Huston, 2010). Remund (2010) described five domains of financial literacy, namely: 1) Knowledge of financial concepts, 2) The ability to communicate about financial concepts, 3) The ability to manage personal finances, 4) The ability to make financial decisions, 5) Confidence while making future financial plans.

Financial literacy includes the ability to discern financial options, raise money, plan for the future, and respond competently to life events that affect day-to-day financial decisions, including events in the economy in general. Financial literacy occurs when an individual has a set of skills and abilities to utilize the existing resources in order to achieve certain personally preset goals. 
Financial literacy is a combination of individual abilities, knowledge, attitudes and ultimately individual behavior, all being related to money. Thus, it can be concluded that financial literacy is an individual's knowledge of finances and also the individual's ability to make effective financial decisions.

\section{Lifestyle}

Lifestyle can be defined as how a person lives, including how someone uses their money, allocates their own time and so on. According to Kotler (2002) as cited in lifestyle is a person's way of living in the world which is expressed in their activities, interests and opinions. In general, a person's lifestyle can be seen from the routine daily activities performed, from what they think about everything around them and how much they care about it and also what they think about themselves and also the outside world. According to Kotler \& Armstrong (2008) and Risman et al. (2021), lifestyle reflects the entire person in their interactions with their environment. This person's interaction with their environment cannot be separated from the influence of people and their surroundings.

Lifestyle describes the entire pattern of a person acting and interacting in the world. Lifestyle shows how people live, how they spend money, and how they allocate time. Therefore, it can be concluded that a lifestyle is a certain general pattern expressed in individual activities, interest and habits, namely, in part of spending money and allocating time (Mowen \& Minor, 2008). The main factors forming a lifestyle can be divided into two large and diverse groups — demographic and psychological factors.

\section{Financial Behavior}

According to Kholilah \& Iramani (2013), financial behavior is the individual's ability to manage finances responsibly. According to (Nababan \& Sadalia, 2012), financial behavior is a discipline in which the interaction of various disciplines demonstrates continuous integrity. Financial behavior describes how a person treats, manages, and uses various financial resources he/she has at their disposal. A person who is responsible for their own financial behavior, namely, for budgeting, saving money, controlling expenses, making investments, and paying debts on time.

According to (Nababan \& Sadalia, 2012), the indicators of financial behavior include: (1) paying bills on time; (2) making expenditures and calculating expenditure budgets; (3) recording expenses/expenditures; (4) providing funds for unexpected expenses; (5) saving periodically; (6) comparing prices between stores in order to make smart purchasing decisions.

Herawati (2015) said that financial behavior is a behavior in managing one's own personal finances, for example, regulating the use of pocket money. Money management overall is the process of controlling and using financial assets (Andrew \& LInawati, 2014). Thus, financial behavior is the behavior revealed while managing, using, controlling personal finances. Financial behavior directly affects financial decision-making.

\section{The Effect of Income on Financial Behavior}

Income is an indicator for measuring welfare of a person/family/household/community.

Only with income, the economic progress of a society would appear (Luminatang, 2013). John et al. (2009) proved there is a positive relationship between income and responsible financial management behavior. This means that the higher the income, the better and more 


\section{IS BEHAVIOR FINANCE AFFECTED BY}

responsible the financial behavior. The results of their study have been supported by the perspective theory of financial behavior in adaptive financial decision-making. Improving personal socio-demographic condition would always affect the investment and other financerelated decision-making process. Sudheer (2015) have found that income has a significant effect on investment needs and decisions. Based on the previous research results and assumptions, the authors of this study formulate the following first hypothesis:

$\mathrm{H} 1$ : Income has a positive and significant effect on financial management.

\section{The Effect of Financial Literacy on Financial Behavior}

Financial literacy helps individuals avoid financial problems, especially those that occur due to financial mismanagement. Financial literacy in the form of understanding all aspects of personal finance is not aimed at restricting people from enjoying life. It's the opposite actually, with financial literacy, individuals or families can enjoy life by properly utilizing their financial resources and achieving their personal financial goals.

The research by Ningtyas \&Wafiroh (2019) showed that low financial literacy will have some impact on decision-making in everyday life. Making wrong decisions will end up in poor and ineffective financial management which, in its turn, results in the behavior of people who are vulnerable to financial crises and have the potential to suffer losses due to crime.

Based on the previous research results and assumptions, the authors formulate the following hypothesis:

H2: Financial literacy has a positive and significant effect on financial behavior.

\section{The Effect of Lifestyle on Financial Behavior}

A specific lifestyle leads to certain consumption patterns that describe a person's choice of things and how to spend time and money. According to Kotler and Armstrong (2008), lifestyle is to reflect the entire person in their interactions with the environment. A person's interaction with their environment cannot be separated from the influence of people and their surroundings. Lifestyle describes the entire pattern of a person acting and interacting in the world.

The research conducted by Sari et al. (2020) shows that lifestyle has an influence on financial management behavior: individuals who have good financial management skills will certainly control costs so that money can be allocated properly according to these individuals' needs. Also, an increasing person's lifestyle will also increase their financial behavior. Based on such previous research statements, the authors formulate the following hypothesis:

H3: Lifestyle has a significant influence on financial behavior.

\section{Research Methodology}

\section{Types of Research and Data Collection Techniques}

This research is quantitative in type and nature. The data is processed using the SPSS. The key data source used in this research is primary data collected by means of the survey method. The analytical tool used in this study is multiple regression analysis. The data measuring instrument is Likert scale. 


\section{Population, Sample and Sampling Technique}

The population in this study were students of the Faculty of Economics \& Business, University of Mercu Buana Jakarta, Indonesia. There were 50 respondents, and the number of statements is 28 items. The sampling technique used in this study was simple random sampling.

\section{Data Analysis Method}

a. Classic assumption test

1) Normality Test

The normality test used in this study is the Kolmogorov-Smirnov Z (1 Sample KS).

If the value is Asymp. Sig. < 0.05, it means that the distribution is not normal, and on the contrary, if the Asymp value. Sig. > 0.05, it means that it is normally distributed.

\section{2) Multicollinearity Test}

There are several criteria for detecting multicollinearity as follows:

By looking at the tolerance value. If the tolerance value is greater than 0.10 , then multicollinearity does not occur, and vice versa - if the tolerance value is smaller than 0.10 , then multicollinearity occurs.

By looking at the VIF (Variance Inflation Factor) value: if the VIF value is greater than 10 , then multicollinearity occurs, whereas if it is smaller than 10 then multicollinearity does not occur.

3) Heteroscedasticity Test

The heteroscedasticity test aims to check whether there are variable inequalities from the residuals of one observation to another in the regression model. If the residual variance from one observation to another observation remains, it is called homoscedasticity and if it is different - it is called heteroscedasticity.

\section{b. Hypotheses testing}

1) Multiple Linear Regression Test

Multiple regression equation is a regression equation operating two or more independent variables. The general form of a multiple linear regression equations is:

$$
\mathrm{Y}=\mathrm{a}+\mathrm{b} 1 \mathrm{X} 1+\mathrm{b} 2 \mathrm{X} 2+\mathrm{b} 3 \mathrm{X} 3=\ldots=\mathrm{e}
$$

\section{2) Partial Test (T Test)}

This test aims to determine the influence of one explanatory variable individually in explaining the variation in the dependent variable. Where Ho is the success parameter equal to zero, and Ha the parameter of a variable that is not equal to zero. Basis for decisionmaking:

If the probability (significance ) $>0.05$ or $t$ count $<\mathrm{t}$ table, then the hypothesis is not proven, thus, Ho is accepted, and $\mathrm{Ha}$ is rejected.

If the probability (significance) $<0.05$ or $\mathrm{t}$ count $>\mathrm{t}$ table, then the hypothesis is proven, Ho is rejected, and Ha is accepted. 


\section{IS BEHAVIOR FINANCE AFFECTED BY}

\section{3) Simultaneous Effect Test (F Test)}

This test is carried out to check whether all the independent variables have a joint influence on the dependent one. With a significance level of 5\%, the test criteria are as follows:

If the significance value $\mathrm{f}<0.05$, then $\mathrm{H} 0$ is rejected. Thus, there is a significant influence between all the independent variables on the dependent variable.

If the significance value $\mathrm{f}>0.05$, then $\mathrm{H} 0$ is accepted. Thus, there is no significant effect between all the independent variables on the dependent variable.

4) The Coefficient of Determination (R2)

The coefficient of determination ( $\mathrm{R}$ square) basically measures the model's ability to explain the variation in the dependent variable. The coefficient of determination is between zero or one. The small $\mathrm{R}$ square value means that the ability of the independent variable to explain the variation in the dependent variable is very limited.

\section{Results and Discussion}

\section{a. Validity and Reliability Test}

Based on the results shown in Table 1, the validity and reliability tests show that for income, financial literacy, lifestyle and financial behavior (through the Pearson correlation) all the statement items are valid, as indicated by the probability value $<0.05$.

The results of testing the reliability of all the instruments through the Cronbach Alpha test show that all the instruments are reliable, as indicated by the Cronbach Alpha value being $>0.60$.

\section{b. Classic assumption test}

1) Normality Test

Table 1.Normality Test Results

(One-Sample Kolmogorov-Smirnov Test)

\begin{tabular}{|l|c|}
\hline \multicolumn{1}{|c|}{ Normal Parameters } & Value \\
\hline$\underline{\text { Mean }}$ & 50.0000000 \\
\hline Std. Deviation & 3.11002448 \\
\hline Absolute & 0.118 \\
\hline Positive & 0.109 \\
\hline Negative & -0.118 \\
\hline Statistical Test & 0.118 \\
\hline
\end{tabular}

Base on data Tab. 1, the normality test shows that the Asymp. Sig of 0.079 is greater than the significance value of 0.05 . Thus, it can be stated that the data is normally distributed and it can pass the normality test. 
2) Multicollinearity Test

Table 2 - Multicollinearity Test Results Dependent Variable: financial behavior

(Own results obtained in SPSS 25)

\begin{tabular}{|l|c|c|}
\hline \multicolumn{1}{|c|}{ Variable } & \multicolumn{2}{c|}{ Collinearity Statistics } \\
\hline & Tolerance & VIF \\
\hline Income & 0.631 & 1,584 \\
\hline Financial literacy & 0.786 & 1,273 \\
\hline Lifestyle & 0.602 & 1,662 \\
\hline
\end{tabular}

Bare on dataTable 2 with its multicollinearity test results, it can be stated that the income variable (X1) obtained a tolerance value, $0.631>0.10$ and VIF $1.584<10$.

Then, the Financial Literacy Variable (X2) obtained a tolerance value, $0.786>0.10$ and VIF $1.273<10$. The Lifestyle Variable (X3) obtained a value of $0.602<0.10$ and VIF 1.662 $<10$.

Therefore, from the multicollinearity test results, it can be concluded that there is no multicollinearity among the independent variables.

3) Heteroscedasticity Test

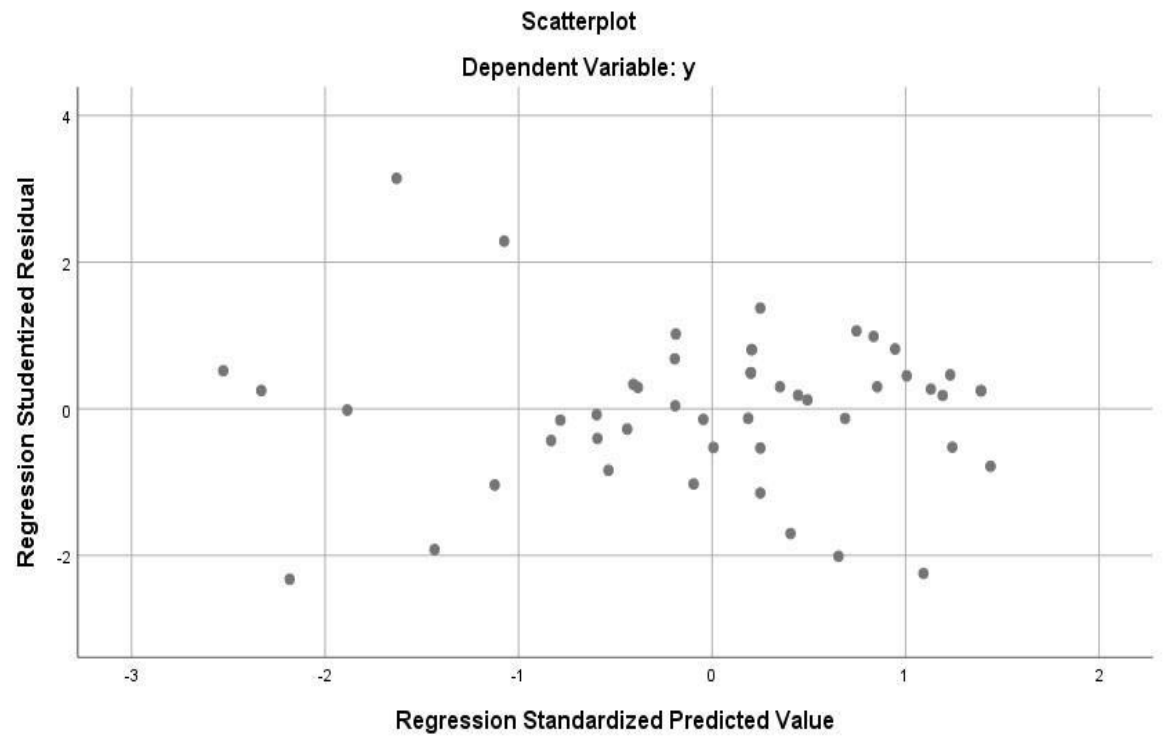

Figure 1 - Heteroscedasticity Test Results

(Data source: Own results calculated in SPSS 25, 2021)

Looking at Fig. 1 above, we can tell the following about the heteroscedasticity test results:

- data points are spread relatively equally 


\section{IS BEHAVIOR FINANCE AFFECTED BY}

- the spread of data points overall does not form a wavy pattern that would be widened, then narrowed and then widened again

- the distribution of data points is not patterned as such.

Thus, it can be concluded that there is no problem of heteroscedasticity, and a good, even almost ideal regression model can be fulfilled.

\section{Hypotheses testing}

1) Multiple Linear Regression Test

Table 3 - Multiple Regression Test Results (Coefficients)

(Source: Own results calculated in SPSS)

\begin{tabular}{|c|c|c|c|c|c|}
\hline \multicolumn{2}{|c|}{$\begin{array}{c}\text { Unstandardized Coefficients B } \\
\text { Std. Error }\end{array}$} & $\begin{array}{c}\text { Standardized } \\
\text { Coefficients Beta }\end{array}$ & $\mathrm{t}$ & Sig. \\
\hline (Constant) & 1,019 & 3,432 & & .297 & .768 \\
\hline $\mathrm{x} 1$ & .194 & .130 & .169 & 1,489 & .143 \\
\hline $\mathrm{x} 2$ & .596 & .109 & .558 & 5,483 & .000 \\
\hline $\mathrm{x} 3$ & .205 & .102 & .233 & 2005 & .051 \\
\hline
\end{tabular}

Stemming from Tab. 3 above, we can now present the equation model as follows:

$$
\begin{gathered}
\mathrm{Y}=\mathrm{a}+\mathrm{b} 1 \mathrm{X} 1+\mathrm{b} 2 \mathrm{X} 2+\mathrm{b} 3 \mathrm{X} 3, \\
\mathrm{Y}=1.019+0.194 \mathrm{X} 1+0, .596 \mathrm{X} 2+0, .205 \mathrm{X} 3
\end{gathered}
$$

where:

$\mathrm{Y}=$ Fiancial Behavior

$\mathrm{A}=$ Constant Value

$\mathrm{X} 1$ = Income

$\mathrm{X} 2=$ Financial Literacy

X3 = Lifestyle

Base on the equation it can be concluded as follows:

Constant Value (a) $=1.019$. This means that if the influence of Income, Financial Literacy and Lifestyle does not exist or is worth 0, then Financial Behavior will increase by 1,019 .

Income $(\mathrm{X} 1)=0.194$. This means that income has a positive effect on financial behavior. The coefficient means that for every one unit increase in income, financial behavior may decrease by 0.194 .

The coefficient is positive, meaning that income has a positive relationship with financial behavior, meaning that with every increase in income, financial behavior would be decreasing.

Financial Literacy $(\mathrm{X} 2)=0.596$. This shows that financial literacy has a positive effect on financial behavior. The obtained result means that every one unit increase in financial 
literacy would lead to financial behavior increasing by 0.596 . The positive value coefficient means that financial literacy has a positive relationship with financial behavior. In other words, with every increase in financial literacy, the possibility of a wrong financial behavior will be smaller.

Lifestyle $(\mathrm{X} 3)=0.205$. Work discipline always affects financial behavior in the most positive way. This coefficient can be interpreted as follows: every one-unit increase in a lifestyle leads to financial behavior increasing by 0.205 .

The positive value coefficient means that lifestyle has a positive relationship with financial behavior.

2) Partial Test (T-test)

\section{The Effect of Income on Financial Behavior}

Our very first hypothesis was that income has a positive effect. Based on the results of the hypotheses testing (see Tab. 4), the t count is $1.489<2.01290$, and the significance is $0.143>0.05$. This shows that income has a positive but rather insignificant effect on financial behavior. Therefore, the first hypothesis $(\mathrm{H} 1)$ is rejected.

\section{The Effect of Financial Literacy on Financial Behavior}

The second hypothesis is that financial literacy has a positive effect on financial behavior. From the results of the hypotheses testing (see Table 4), the t count is 5,483 > 2,01290 , and the significance value is $0,000<0.05$. This shows that financial literacy has a significant effect on financial behavior. Therefore, the second hypothesis is accepted.

\section{The Effect of Lifestyle on Financial Behavior}

The third hypothesis is that lifestyle has a positive effect on financial behavior. Based on the results of the hypotheses testing in Table 4, the $t$ count is $2.005<2.01290$, and the significance is $0.051>0.05$. In other words, this study cannot prove that lifestyle has a significant effect on financial behavior. Therefore, the third hypothesis is rejected by us.

3) Simultaneous Test (F Test)

Table 4 - ANOVA =F-Test Results

(Dependent Variable: is y)

\begin{tabular}{|l|c|c|c|c|c|}
\hline \multicolumn{1}{|c|}{ Item } & Sum of Squares & Df & Mean Square & F & Sig. \\
\hline Regression & 793,580 & 3 & 264,527 & 25,675 & $.000 \mathrm{~b}$ \\
\hline Residual & 473,940 & 46 & 10,303 & & \\
\hline Total & 1267,520 & 49 & & & \\
\hline
\end{tabular}

Data presented in Tab. 4 above shows the results of statistical processing in the context of our regression analysis, namely, the value of F-count is 4.515 with the significance value being $0.000<0.05$. This shows that the regression analysis tool used in this study is feasible and can be used to predict the independent variables (income, financial literacy, and lifestyle in our particular base) on the dependent variable (the financial behavior). 


\section{IS BEHAVIOR FINANCE AFFECTED BY}

4) Testing the Coefficient of Determination (R2)

Table 5- Determination Coefficient for Test Results

\begin{tabular}{|c|c|c|c|}
\hline $\mathrm{R}$ & R Square & Adjusted R Square & Std. Error of the Estimate \\
\hline $.791 \mathrm{a}$ & .626 & .602 & 3.20984 \\
\hline
\end{tabular}

Table 5 shows that the value of $\mathrm{R} 2$ is 0.626 , or $62.6 \%$. This means that the variables of income, financial literacy, and lifestyle have the $62.6 \%$ effect on financial behavior. The remaining $27.4 \%$ assume the influence by other variables that are not covered by our research model.

\section{Discussion}

\section{The Effect of Income on Financial Behavior}

Basing on the results of statistical data processing presented in this study, we can state that our hypothesis $1(\mathrm{H} 1)$ has been rejected. After the multiple regression testing, the coefficient value is 0.194 . This is shows that income has a positive effect on financial behavior. The first hypothesis has the calculated $t$ value of $1.489<2.01290$ and the significance value of $0.143>0.05$. This means that income does not have a really significant effect on financial behavior. When income increases or decreases, the change will not affect financial behavior.

This phenomenon can be explained by pointing out that individuals with high income levels are not always really able to manage their expenses in a good way, mainly due to irresponsible financial behavior and the tendency to think in a short-term manner.

\section{The Effect of Financial Literacy on Financial Behavior}

Looking at the results of the statistical data processing carried out in this study we can state that hypothesis 2 can be accepted. In the related multiple regression testing, the coefficient value is 0.596 , this shows that financial literacy has a positive effect on financial behavior.

The second hypothesis also has a calculated t-value of 5,483>2,01290 and the significance value of $0,000<0.05$. This means that financial literacy has a significant effect on financial behavior.

These results support the research results of Ningtyas \&Wafiroh (2019) who proved that the more someone knows about financial literacy, the more capable that person would be in their reasonable financial behavior. In this context, good financial behavior covers such aspects as financial planning, the ability to save, the discipline to pay bills on time, etc.

\section{The Effect of Lifestyle on Financial Behavior}

According to the results of our statistical data processing we can state that hypothesis 3 is rejected. In the carried out here multiple regression testing, the coefficient value is 0.2005 . This means that lifestyle has a positive effect on financial behavior. 
The third hypothesis has the calculated t value of $2.005<2.01290$ and the significance value of $0.051>0.05$. This means that lifestyle does not have a significant effect on financial behavior.

Interpreting the results of this study we need to keep in mind that our respondents come from various backgrounds, thus, they have diverse lifestyles. However, these respondents with their various lifestyles do not actually show differences when it comes to real-life financial behavior.

\section{Conclusion, Limitations and Recommendations}

\section{Conclusion}

Considering the research results and their discussion above, the following conclusions can be drawn:

- Personal income level does not have a significant effect on financial behavior.

- Financial literacy has a significant positive effect on financial behavior.

- Lifestyle does not have a significant effect on financial behavior.

\section{Limitations} namely:

Just as any other research study based on a survey, this study has some limitations,

- Some of the respondents in this study did not demonstrate any specific lifestyle.

- This study has been using three variables only. This means that the effect on the dependent variable has not been analyzed in full.

- This study has used a sample limited to Mercu Buana Faculty of Economics and Business students only. Thus, we had not only a small number of the respondents but also a rather homogenous group of them.

\section{Recommendations}

Stemming from the results and limitations of this study, the authors would like to provide several suggestions for further research in the same or similar direction:

1) Adding other variables which are not included in this research;

2) Increasing the number of the respondents, so that the results obtained would be more accurate.

\section{References:}

Andrew, V. \& Linawati, N. (2014). The Relationship between Demographic Factors and Financial Literacy with Employee Financial Behavior in Surabaya. Finesta, 2(2).

Dwinta, I. C. (2010). The influence of locus of control, Financial Knowledge, and income on financial management behavior. Journal of Business and Accounting, 12 (3), 131-144.

Financial Services Authority (2017). Implementation of Activities in Improving Financial Literacy in The Financial Services Sector. Available at: https://www.ojk.go.id/.

Fudyartanta, K. (2012). Personality Psychology. Yogyakarta: Student Library.

Herawati, N. (2015). Contribution of Learning in Higher Education and Financial Literacy on Student Financial Behavior. Journal of Education and Teaching, 48 (1-3). 


\section{IS BEHAVIOR FINANCE AFFECTED BY}

Hilgert, M. et al. (2003). Household Financial Management : The Connection between Knowledge and Behavior. Federal Reserve Bulletin, 89(7), 309-322.

Huston, S. J. (2010). Measuring financial literacy. The Journal of Consumer Affairs, 44(2), 296-316.

John, G. E. Et al. (2009). Explaining Financial Management Behavior for Koreans Living in the United States. The Journal of Consumer Affairs, 80.

Kholilah, N. A. \& Iramani. R. (2013). Study of Financial Management Behavior in Surabaya Society. Journal of Business and Banking, 3(1), 69-80.

Kotler, P. (2002). Marketing Management. PT Prenhallindo, Jakarta.

Kotler, P. \& Armstrong, G. (2008). Principles of Marketing. Erlangga, Jakarta.

Luminatang (2013). Income Analysis of Rice Farmers in Teep Village, East Langowan District. Journal of EMBA 991, 1 (3), 991-98.

Mowen, J. C. \& Minor, M. (2002). Consumer Behavior. Erlangga: Jakarta.

Nababan, Darman, \& Sadalia, I. (2012). Analysis of Personal Financial Literacy and Financial Behavior for Undergraduate Students of the Faculty of Economics. University of Northern Sumatra.

Ningtyas, N. et al. (2019). How is Financial Literacy and Behavior in Millennial Generation? Business Review, 20 (1).

Remund, D. L. (2010). Financial Literacy Explicated: The Case for a Clearer Definition. Increasingly Complex Economy, 44(2), 276-295.

Risman, A., Prowanta, E. \& Siswanti, I. (2021). Behavioral Corporate Finance. Yogyakarta. Penerbit KBM Indonesia.

Sari, S. R., Andriani, S. \& Kemala Sari, P. R. (2020). The Influence of Financial Literacy and Lifestyle on the Financial Behavior of Female State Civil Apparatus (ASN) in Sumbawa Besar. Indonesian Journal of Economics and Business, 05 (02), 33-37.

Sudherr, V. (2015). Impact of Socioeconomic Factors on Investors' Investment Culture. The International Journal of Business and Management, 3 (7).

Paper submitted

Paper accepted for publishing

Paper published online
02 May 2021

O6 July 2021

31 July2021 